\title{
A guide to the biology and taxonomy of the Echinosteliales
}

\author{
Haskins EF $^{1}$ and Clark $\mathbf{J}^{2}$ \\ ${ }^{1}$ Department of Biology, University of Washington, Seattle, Washington 98195 \\ ${ }^{2}$ Department of Biology, University of Kentucky, Lexington, Kentucky 40506
}

Haskins EF, Clark J 2016 - A guide to the biology and taxonomy of the Echinosteliales. Mycosphere 7(4), 473-491, Doi 10.5943/mycosphere/7/4/7

\begin{abstract}
This guide is an attempt to consolidate all information concerning the biology of the Echinosteliales, including uniform species descriptions for all of the species, and to make this available to interested persons in an open access journal. The Echinosteliales are a small group of myxomycetes with relatively minute sporangia and a unique plasmodial trophic stage (a protoplasmodium). These protoplasmodia, which are a defining characteristic of the order, are relatively small (20-150 $\mu \mathrm{m}$ in diameter) amoeboid stages with sluggish protoplasmic streaming and plasmodial movement which, as far as it is known, do not form a reticulum or undergo fusion with other plasmodia, but do undergo binary plasmotomy after reaching an upper size limit with each plasmodium produces a single sporangium. The minute sporangia produce a relatively limited number of spores and, except for one stalk-less species, they have a distinctive stalk consisting of a fibrillose tube having amorphous material in the lower region and closing at the upper end to produce a solid region. This morphology, along with developmental and DNA studies indicate that this order is probably the evolutionary basal group of the dark-spored myxomycetes.
\end{abstract}

Key words - amoeboflagellate - Barbeyella - Clastoderma - Echinostelium - plasmodium Semimorula - sporangia

\section{Introduction}

The minute sporangia of Echinostelium minutum, Clastoderma debaryanum and Barbeyella minutissima were discovered and named between 1874 and 1914. However, they were seldom collected and little was known of their developmental history except for Guliema Lister's early studies on spore germination, swarm cells and dividing myxamoebae; see Haskins (1988) for a discussion of her workbooks. However, it was the culture studies of Alexopoulos (1960), Olive (1960), and McManus (1961) that determined their basic biology and stimulated the search for additional species; with the descriptions of thirteen new Echinostelium species, two new Clastoderma species, and a new genus and species Semimorula liquescens (Haskins et al. 1983). The Echinosteliales are a relatively small order of myxomycetes with minute sporophores, that are generally designated sporocarps (produce internal spores) and they have a distinctive shape and size and are therefore sporangia. These sporangia, except for their minute size, are similar in structure and form to the vast majority of the sporocarps of the other orders of myxomycetes. Sporangia normally consist of two parts - the sporotheca which contains the spores, and the stipe which lifts the sporotheca off of the substrate (presumably for better spore dispersal). The stipe, which is present in all but one species in the order, consists of three continuous regions: the 
hypothallus which attaches the stipe to the substrate, the stalk which is the support of the sporotheca, and the columella which is an extension of the stalk into the sporotheca and attaches it to the stalk. Besides the spores, the sporotheca may contain a network of branching and anastomosing threads (capillitium) which support the spore mass and an outer covering (peridium) which breaks down at maturity to release the spores. The spores, when they germinate, release the unicellular and uninucleate amoeboflagellate trophic stage; and after a period of growth the amoeboflagellate stage produces the multinucleate plasmodial trophic stage. The plasmodium, after a period of growth and, as far as it is known, plasmotomy (binary division after reaching a maximum size), then differentiates into sporangia to complete the life cycle. This alternation between the trophic stages can involve either a sexual or apogamic nuclear cycle (see Clark \& Haskins 2013).

\section{Trophic Stages}

The majority of the information on the trophic stages of Echinosteliales was derived from studies involving Echinostelium minutum. Microscopic cinematography (Haskins 1973a, 1973b) of these stages can now be viewed on line by going to TIB: AV-Portal, opening the portal and searching for Haskins to find the specific films.

\section{Amoeboflagellates}

All three of the amoeboflagellate states are colorless, microscopic and usually haploid uninucleate cells with morphologies that are adapted to their life cycle functions; these are the generalist myxamoebae, the swimming swarm cell and the resistant cyst. The microscopic (approximately $10 \mu \mathrm{m}$ in diameter) uninucleate myxamoebae have the pleomorphic shape common to soil amoebae which lack a cell wall. The interior of the cell contain small, but normal eukaryotic organelles: a nucleus with a double membrane and a nucleolus, numerous tubular cristae mitochondria similar to those found in many other protozoan amoebae, an endoplasmic reticulum, a Golgi apparatus, a contractile vacuole, two centrioles, and food vacuoles (Aldrich 1968). Swarm cells have an elongated shape with a cone-shaped anterior and a wider somewhat amoeboid posterior region. The flagella, centrioles and nucleus are located at the anterior region, which is shaped and maintained by a conical arrangement of microtubules (Aldrich 1968). The posterior region contains mitochondria, a contractile vacuole and other organelles; it also produces pseudopodia which adhere to bacteria and other food particles which are ingested into food vacuoles. Each swarm cell usually has two heterokont whiplash flagella, one of which is normally short and carried pressed to the cell membrane where it is difficult to detect (Elliott 1949). While, there are numerous reports of one to eight flagella per cell, the most common number within most specific cultures is two per cell (Elliott 1949, Haskins 1978a). However, some forms that have been reported appear to be normal variations or developmental abnormalities, as in Echinostelium minutum where the flagella are always isokont (equal in size), and some swarm cells, from the same isolate, have varying numbers (1-8) of flagella (Haskins 1978a) possibly due to polyploidy. The resistant cyst is derived from the myxamoeba by the rounding up of the amoeboid cell, condensation of the cytoplasm, disappearance of food vacuoles and contractile vacuole, and the formation of a cyst wall (Koevenig 1964). The cyst wall consists of one to several randomly arranged microfibril layers (depending upon the species), which may display small spine-like ornamentations (Haskins et al. 1985). While excystment in most myxomycete species occurs by means of a pore dissolved in the wall (Aldrich \& Blackwell 1976), in Echinostelium minutum the cyst wall completely dissolves (Haskins et al. 1985). The myxamoebae and swarm cells are generally believed to be capable of multiple reversible transformations between the two forms, although Ross (1957) believed that some species lose the ability to reversibly transform after a period of growth and thereafter remained either myxamoebae or swarm cells. Myxamoebae transform into swarm cells by the formation of centrospheres on the nuclear membrane, consisting of the Golgi apparatus and centrioles, which then move to the cell membrane and elongates the nucleus and cell with the formation of a microtubular cone structure (Aldrich 1968). This forms the 
anterior end of the swarm cell and the remaining cytoplasm and organelles move to the other end of the cell to produce the posterior end. The flagellar sheath is then produced by the Golgi vesicles and the inner flagellar microtubules are formed from the basal bodies (Aldrich 1968). Swarm cells transform into myxamoebae by absorbing the flagella, either by whipping it against and fusing with the cell membrane or pulling it in by movement of the nucleus, as the cone structure disperses (Koevenig 1964).

\section{Plasmodia}

Plasmodia are produced by the amoeboflagellate stage via the formation of a diploid zygotic cell by means of sexual fusion, or by the conversion of an apogamic diploid amoeboflagellate into a plasmodium (see reviews by Clark \& Haskins [2010, 2013]). In the sexual cycle amoeboflagellates differing at a multiple allelic mating system undergo syngamy after they have become competent upon reaching a critical cell density (Shipley \& Holt 1982); while in the apogamic cycle, the amoeboflagellates are diploid, due to automixis (see Clark \& Haskins 2013), and convert to plasmodia when they become competent. The zygotic or diploid amoeboflagellate cell apparently undergo a number of biochemical changes in their cell membrane (Ross \& Shipley 1973) and a series of mitotic nuclear divisions without cell division to produce the multinucleate plasmodium. The reproductive cycle in the Echinosteliales has been examined in only two species: Echinostelium minutum and E. coelocephalum. Seventeen sexual heterothallic isolates of Echinostelium coelocephalum were isolated from California and Arizona desert plant detritus and were found to contain a minimum of thirteen different mating types (Haskins et al. 2000); the exact number of mating types could not be determined due to high levels of sterility in some mating type isolates. Seven sexual heterothallic isolates of Echinostelium minutum were also isolated from California and Arizona desert plant detritus and were found to consist of two separate biological species which did not interbreed; the six California isolates formed one biological species containing four different mating types, with the single Arizona isolate forming a separate biological species (Clark \& Haskins 1998). However, most isolates of E. minutum have been found to be nonheterothallic (see Clark \& Haskins 2010), in that isolated single spore clonal populations can form plasmodia by themselves. These isolates apparently do not undo a nuclear ploidal change during the reproductive cycle (Haskins \& Therrien 1978); however, synaptonemal complexes (indicators of meiosis) have been found in the maturing spores (Haskins et al. 1971). These conflicting results were resolved by the finding that this division is automictic (the second division of meiosis is suppressed); therefore, there is no ploidal change (Therrien \& Haskins 1981) in the nonheterothallic isolates. Therefore, Echinostelium minutum is a species complex consisting of several sexual biological species and numerous non-heterothallic clonal lines.

The Echinosteliales have a distinctive protoplasmodium, which is considered to be one of the defining characters of the order. The uninucleate initial plasmodial cell undergoes nuclear division to form the characteristic mature protoplasmodium, which is a microscopic (20-150 micron diameter) multinucleate generally colorless amoeboid cell with many short pseudopodia on its periphery and a heavy slime sheath (Alexopoulos 1960, Haskins \& Hinchee 1974). It migrates very slowly over the substrate, exhibiting slow irregular cytoplasmic streaming, and does not produce an advancing fan-shaped region, although it can display an anterior/posterior orientation. Unlike the other two plasmodial types (phaneroplasmodia and aphanoplasmodia) it does not produce a reticulated plasmodium or fuse with either itself or any other plasmodium (Haskins 1978b). Upon reaching a upper size limit the protoplasmodium, as far as it is known, undergoes binary plasmotomy to produce two daughter plasmodia (Haskins 1978b), and upon sporulation, each protoplasmodium produces a single sporangium as reported for Echinostelium minutum (Alexopoulos 1960), Clastoderma debaryanum (McManus 1961), and Barbeyella minutissima (Schnittler et al. 2000). These plasmodia probably represent the ancestral form for all of the myxomycetes, and appear to be evolved for residence in ephemeral habitats on the surfaces of plants and plant debris. The plasmodia of Echinostelium apitectum, E. brooksii, E. ladoi, E. paucifilum, and Clastoderma microcarpum are unknown, and the remaining species all have 
hyaline protoplasmodia, with the exceptions of E. fragile, E. lunatum and E. minutum which may have pinkish plasmodia, $C$. debaryanum which has a dirty white plasmodium that turns greenish to blackish with age, and Barbeyella minutissma that has a white plasmodium which turns dark brown with age. Echinostelium bisporum has a unique hyaline uninucleate amoeboid cell instead of a plasmodium.

A plasmodium subject to adverse environmental conditions can form a sclerotium; this dormant stage is not required to complete the life cycle, but may be important under certain circumstances, where growth is interrupted due to short or long term unfavorable conditions where this characteristic may be especially valuable to species that inhabit extreme environments such as deserts, snow-banks or the bark of trees, where rapid swings in temperature and moisture may occur. The basic structure of the sclerotium is the spherule; a round to ovoid cell of variable size (up to 25 microns in diameter) with an amorphous fibrous wall (Aldrich \& Blackwell 1976) and a variable (0 to 14) number of nuclei (Jump 1954). While most myxomycete species form a sclerotium with multiple spherules, each protoplasmodium of Echinostelium minutum forms a single cyst (spherule) with a wrinkled single layered fibrillar wall (Haskins et al. 1985). Once, favorable growth conditions reoccur, these resistant structures rapidly (in 3 to 24 hours) excyst and return to normal plasmodial activities (Haskins et al. 1985).

\section{Culture and Ecology}

A number of Echinosteliales species have been grown in agar culture with a bacterial or yeast food associate. These are E. arboreum (Haskins \& McGuinness 1989), E. bisporum (Olive \& Stoianovitch 1966), E. coelocephalum (Haskins et al. 2000), E. colliculosum (Haskins and McGuinness personal communication), E. corynophorum (Haskins \& McGuinness 1986), E. lunatum (Olive \& Stoianovitch 1991), E. minutum (Alexopoulos 1960), S. liquescens (Haskins et al.1983, and C. debaryanum (McManus 1961). These species were generally grown on a weak nutrient agar (often with a substrate extract) containing a food organisms isolated from the substrate (Haskins \& Wrigley de Basanta 2008). However, E. minutum is the only species to be grown axenically without a live food associate (Haskins 1970). This medium is fairly complex (fetal calf serum, liver concentrate, protease peptone, yeast extract, glucose, $\mathrm{KCl} . \mathrm{NaCl}, \mathrm{CaCl}_{2}$ with a final $\mathrm{pH}$ of 6) and only supported myxamoebal and not plasmodial growth.

Little is known about the ecology of the Echinosteliales species, since their minute size generally restricts their study in nature. However, on the basis of moist chamber cultures, most species appear to be widely distributed and are generally found on the bark of living trees, with occasional collections on vines, dead plant stalks and other plant detritus; only Echinostelium lunatum and Semimorula liquescens, both extremely minute and studied by a single researcher, have restricted collection distributions. As far as it is known, Semimorula liquescens is restricted to the dried infructescences of Solidago and Lythrum spp. (Haskins et al. 1983) and the dried leaves of Phragmites spp. (Haskins, unpublished data). The habitat of Barbeyella minutissima, on the other hand, appears to be distinct in that it seems to be restricted to montane spruce forests and decaying logs with associated mosses, liverworts and algae (Schnittler et al. 2000).

\section{Sporangia}

Most species in the order produce minute stalked fruiting bodies containing a limited number of spores in a fugacious spherical sporotheca, with the exception of Semimorula liquescens which has a sessile sporotheca.

\section{Stalk and Hypothallus}

The stalks of the stipitate species of Echinosteliales consist of a cylindrical tubular structure of fibrillar strands and amorphous material which are generally filled with granular material in the lower regions and generally closed in the upper regions to form a solid cylinder (McManus 1961, Alexopoulos 1969). This stalk type is unique and is considered to be one of the defining characteristics of the order (Alexopoulos 1969, Haskins and McGuinness 1989). The only divergent 
species from this stalk type are Semimorula liquescens, which is sessile, and Echinostelium bisporum, which is a minute species with a simple tube stalk which may have granules in the lower regions. The stalk of Clastoderma debaryanum is also somewhat unique in that it generally has a bubble-like swelling of the stalk at the junction of the hollow and solid parts of the tube. The stalks in most species of Echinostelium are translucent and generally vary in color from hyaline to a pale yellow, a pale yellowish-brown or a pale brown; however, E. cribrarioides (varying to dark brown) and $E$ elachiston (golden yellow) may display a more distinctive coloration. In the Clastoderma species the upper portion is translucent and either brown $(C$. debaryanum) or reddish-brown $(C$. microcarpum and $C$. pachypus), with the granular material in the lower portion producing an opaque jet black to dark yellowish brown coloration. However, in Barbeyella minutissma the stalk is generally a uniform dark blackish brown. The hypothallus of all of the stipitate species is produced by the flaring out of fibers at the base of the stalk to produce the small discoid substrate attachment structure, whose color is generally a somewhat darker hue than the stalk.

\section{Columella and Capillitium}

A columella is present in most species and it is a continuation of the stalk and its fibrillar strands into the sporotheca; and in a number of species these fibrillar strands split into smaller bundles to produce the capillitial threads. The columella and capillitia may be absent in some Echinostelium species (E. bisporum, E. coelocephalum, E. colliculosum, E. elachiston and E ladoi), although a minute columella and very rudimentary capillitia may be present in E. elachiston and a spore-like-body may be present on the tip of the stalk in E. coelocephalum, E. colliculosum and E. ladoi. Other Echinostelium species (E. apitectum E. brooksii, E. corynophorum, E. fragile and E. lunatum) may have columella present but lack capillitia; with E. brooksii and E. corynophorum having a short stalked columella with a hemispherical or lenticular tip, E. lunatum having a unique half circular crescent shaped columella, E. fragile having a elongate fusiform columella, and $E$. apitectum having a short flattened, cylindrical or fusiform columella usually covered by a sporelike body. The remaining Echinostelium species (E. arboreum, E. cribrarioides, E. minutum and E. paucifilum) have a short cylindrical columella that branches to form a capillitium; with the capillitia of E. minutum sparsely branching and not anastomosing, E. arboretum and E. paucifilum sparsely branching and anastomosing with free ends, and E. cribrarioides branching and anastomosing to form a globose net with no to few free ends. The non-stipitate Semimorula liquescens, also completely lacks a columella or capillitia. All three species of Clastoderma have a short cylindrical columella which transitions to a sparsely branching and anastomosing capillitium, with $C$. debaryanum having expanding capillitial platelets from which the thin peridium is attached before it is shed (Frederick et al. 1986), C. microcarpum having no capillitial platelets but the peridium is attached at the capillitial nodes before it is shed, and $C$. pachypus having peripheral capillitia loops with small capillitial platelets to which the peridium can be attached before it is shed. The columella of Barbeyella minutissima is a short cylindrical structure which divides to produce a few non branched capillitia that are attached to the peridium by their tips. The columella and capillitia of all of the Echinosteliales species continue the stalk color into the sporotheca with a general lightening of the colors in the capillitia.

\section{Peridium}

The globose to subglobose sporotheca of most Echinosteliales species has a fugacious peridial membrane which in most species rapidly disappears except for a small basal collar that remains attached to the stalk. In the Echinostelium species this peridium is a thin hyaline shiny membranous material with an amorphous structure which disappears at maturity except for a small basal collar around the stalk. However, in some species (E. coelocephalum, E. colliculosum, E. corynophorum, E. elachiston and E. paucifilum) the basal peridial region may be somewhat persistent before it is reduced to a collar; and in E. arboreum peridial fragment remain attached to the capillitial tips and there is a persistent large basal collar. In Semimorula liquescens the thin hyaline peridium completely dissolves at maturity. In the Clastoderma species the peridium is 
dehiscent and may leave small peridial fragments attached to the capillitium platelets or membranous nodes and a basal collar around the stalk; however, the peridium differs in coloration, and attachment to the capillitia: $C$. debaryanum has a rosaceous brown peridium which is completely shed to leave only the platelets of the capillitia, $C$. pachypus has a yellowish brown peridium which is shed to leave only the minute capillitial platelets on the peripheral capillitial loops, and C. microcarpum has a reddish brown peridium which is shed to leave only the peripheral capillitial net. The peridium of Barbeyella minutissima is violaceous, impregnated with dark granules, and splits into five to nine lobes attached to the capillitial tips

\section{Spores}

The spores of the different species are probably the most varied and taxonomically useful of the morphological traits in this myxomycete order, varying in color, size and ornamentation. The spores of the Echinostelium species are described as smooth or minutely roughened by light microscopy; however, electron microscopy (Furtado et al. 1971, Haskins \& McGuinness 1986) has shown micro-ornamentations on a number of species, including microbacula on E. minutum, microechina on E. arboreum and E. bisporum, and microverruca on E. corynophorum and E. coelocephalum. Ultrastructure studies of the spore walls of a number of species of myxomycetes have been found to consist of two layers, an inner electron transparent layer and a thinner electron dense fibrillar outer layer (Scheetz \& Alexopoulos 1971, 1976, Mims 1972). However, the spores of several Echinostelium species display some differences from this norm (Hung \& Olive 1972, Haskins \& McGuinness 1986), with Echinostelium minutum and E. coelocephalum having the normal thicker inner spore layer, E. arboreum and E. corynephorum having equal sized layers, and E. bisporum having a thicker outer layer; and all species having fibrillar channeled sculptured elements in the outer layer that are not present in the species of other orders. While Echinostelium apitectum, E. arboreum and E. bisporum have spore walls of uniform thickness, and E. brooksii, E. fragile and $E$ paucifilum have spore walls with a distinct thinner region, the remaining Echinostelium species have spore walls with distinct raised disjunction pads. Spore size is within the normal range for myxomycete species and is somewhat variable within each species, with $E$. apitectum, E. elachiston, E. ladoi, and E. minutum spores in a 5-8.5 $\mu \mathrm{m}$ diameter range and the remaining species having a 7-15 $\mu \mathrm{m}$ diameter. Spore color is also fairly uniform with most species being hyaline to white, and a few having yellowish to golden hues (E. apitectum, E. coelocephalum and E. elachiston) and others with pinkish or yellowish-pink hues (E. brooksii, E. fragile, $E$. lunatum, E. minutum and E. paucifilum). Semimorula liquescens, another member of the Echinosteliaceae, has a hyaline, 7.5-13 $\mu \mathrm{m}$ diameter spore with only a single loose electron dense fibrillar layer without any channel elements, which makes it more similar to the two protostelid species examined, than to the rest of the Echinosteliaceae (Haskins \& McGuinness 1986). In the Clastoderma species, the spores of $C$. debaryanum are rosaceous brown, 8-10 $\mu \mathrm{m}$ in diameter and are ornamented with blunt warts, the $C$. microcarpum spores are reddish brown, $13.5-15 \mu \mathrm{m}$ and verruculose, and the $C$. pachypus spores are brown, 10-13 $\mu \mathrm{m}$ and faintly spinulose. The spores of Barbeyella minutissima are brown, 7-9 $\mu \mathrm{m}$ in diameter and warted. As far as it is known, the spores of Echinosteliales species germinate via a pore (Haskins \& Hinchee 1992) or a split (McManus 1961), except for Semimorula liquescens, which uniquely germinates by the complete dissolution of the spore wall (Haskins et al. 1983).

\section{Sporangial Development}

Barbeyella minutissima was reported (Schnittler et al. 2000) as probably having an epihypothallic developmental process as seen in several Stemonitis, Comatricha, and Lamproderma species (Jahn 1931, Gray 1937, Ross 1957, Godwin 1961), where the plasmodium first condenses into a pre-sporangial mass which divides into the separate primordial units that form the individual sporangia. After each primodium secretes a hypothallus onto the substrate, it then forms a stalk by secreting a tube composed of fibrillar material by adding to the hypothallus. As the stalk is elongated, by intraprotoplasmic secretion of material to the growing tip which remains enclosed 
within the primordial mass, the developing sporotheca is raised off of the surface. After the stalk reaches its maximum height, the columella and all or much of the capillitium are produced by continued deposition of fibers from the stalk. In some cases, the capillitium is also formed by secretions starting from the peridium and growing to the columella. The sporotheca peridium, which is often thin and fragile, is derived from the protoplasmic membrane and secreted materials. Finally, the spores are cleaved out from the remaining protoplasm into uninucleate units with the secretion of wall materials around them. However, sporangial development in Echinostelium minutum involves the formation of a hemispherical mound in the center of the stationary protoplasmodium (which resembles a fried egg) which becomes the spherical initial that progressively elevates itself atop the tapering fibrillar stipe tube which contains debris and other materials in the lower regions with the columella and capillitia secreted as continuations of the stipe (Haskins 1971, Haskins \& Kerr 1978). The stalk is apparently derived from the basal region of the sporocarp initial so that the stalk is not enclosed in cytoplasmic material as it is progressively extends in length (Haskins 1971, Haskins \& Kerr 1978). Barbeyella is a genus of some interest since it is dark-spored and has been reported as probably having an epihypothallic type development (Schnittler at al. 2000) like the Stemonitales (where it was once placed), but it has lately been placed in the Echinosteliales on the basis of its protoplasmodium, general morphology and DNA studies (Fiore-Donno et al. 2012). Thus, the Echinosteliales, which are considered to a sister group to the Stemonitales (Fiore-Donno et al. 2008, 2009), appears to be similar but different from to the ephihypothallic development type of the Stemonitales (Haskins 1971, Haskins \& Kerr 1978). If this is so, and the Echinosteliales display traits ancestral to the other groups, then a hypothesis concerning the relationships of the developmental types can be constructed. In an ancestral organism with a minute sporocarp, a stalk consisting of a moderately thin outer layer (composed of slime and condensed cytoplasmic materials) with fibers secreted just under it, would produce an extending stalk with the cytoplasmic mass on its apex. In the development of a larger sporangium with a thin weak outer membranous layer, the stipe could be produced by the deposition of extending fibers (with the outer layer non-existent or lost) with the sporogenous mass above and draped over the stalk. While in the development of a larger sporangium with a thick outer layer, the deposition of extending fibers inside a wide column would produce a stalk with the cytoplasmic mass inside and on top, with the final stalk produced by the migration of the protoplasm to the top and a longitudinal pleating of the stalk as it dries. In the Echinosteliales and Stemonitales types, the columella and part of the capillitia would also be formed as a continuation of the stalk, while in the Physarales type, the columella would result from the expansion of the stalk fiber and the laying down of basal peridial-like materials over the stalk tip. The capillitia in the Physarales type of development originate from the peridium and grow to the columella (Weldon 1955), as do the capillitia which form the capillitial surface net in Stemonitales (Ross 1973). Thus the epihypothallic and subhypothallic developmental types are connected and probably derived from an ancestral Echinosteliales system, which represent a third developmental type. While this hypothesis would require some selected developmental studies (especially in Clastoderma, Barbeyella and Echinostelium arboreum) to be validated, it does have the current virtue of providing an explanation for the apparently diverse developmental processes found in the myxomycetes, that seemed to run counter to DNA phylogeny (Fiore-Donno et al. 2008). The developmental differences between Stemonitales (epihypothallic) and Physarales (subhypothallic), which appeared to be major, can now be seen as a more or less continuous system connecting the Echinosteliales, Stemonitales and Physarales orders in a manner similar to that detected by DNA phylogeny.

\section{Systematics}

Recent DNA phylogenic studies (Fiore-Donno et al. 2012, Kretschmar et al. 2016) indicated that Clastoderma debaryanum, Barbeyella minutissma and Semimorula liquescens form a monophyletic clade with several Echinostelium taxa. However, one study (Fiore-Donno et al. 2012) also calls into doubt the monophyletic nature of Echinostelium, since E. arboreum forms a group with Barbeyella with which it shares a somewhat persistent peridium attached to the capillitium; 
however, on the other hand Barbeyella could be considered to be a dark spored Echinostelium species. The other study (Kretschmar et al. 2016) indicates that Clastoderma and Barbeyella should probably be put in separate families and that several Clastoderma debaryanum isolates were highly divergent; it also found that Semimorula liquescens was very close to E. corynophorum. These studies also indicated that the Echinosteliales are the basal clade of the dark spored myxomycetes (apparently the Echinostelium species have lost their pigment) and that Clastoderma is the basal clade of the Echinosteliales. Thus, while a useable DNA phylogeny appears to be within reach, the questions raised by the new data would seem to require further studies with additional species before any taxonomic changes are put in place. We will therefore utilize the present morphological phylogenic system (Whitney 1980) in this study.

The minute size of the sporangia means that almost all collections are from moist chambers and their detection generally requires the use of a good dissecting microscope, which means that they are usually collected only by specialist researchers. However, species collections are generally widespread, if somewhat spotty, and it is quite probable that most species are cosmopolitan and somewhat common. For anyone interested in working with this group who wishes to become familiar with their structure and culture, strains of several species (Echinostelium minutum, E. coelocephalum, E. arboreum, and Semimorula liquescens) are available from the American Type Culture Collection.

\section{Taxa}

Uniform descriptions of the taxa have been compiled and modified using Martin \& Alexopoulos (1969), Keller \& Brooks (1976), Whitney (1980, 1982), Eliasson \& Keller (1996), Pando (1999) and the Eumycetozoan Project (2013). Photographic and other illustrations are available, for most of the species, at the Eumycetozoan Project website. Distribution and habitat citations are not meant to be complete, but are used to show the general state of knowledge at the present time.

\section{Key to the families, genera and species}

1. Spores light colored (hyaline, white, pinkish, yellowish, olive gray): Echinosteliaceae - 2 .

1. Spores dark colored (brown to black): Clastodermataceae - 13.

2. Sessile sporangium - Semimorula liquescens

2. Stipitate sporangium: Echinostelium - 3.

3. Capillitium present - 4.

3. Capillitium absent -6

4. Capillitium forming a complete net with no or few free ends - E. cribrarioides

4. Capillitium rudimentary and lacking branching - E. elachiston

4. Capillitium sparsely branching and sometimes anastomosing with free ends -5 .

5. Spores 5-7 $\mu \mathrm{m}$, walls having a uniform thickness; peridium persistent; columella, usually hyaline, stout and up to $30 \mu \mathrm{m}$ in height; sporangia less than $150 \mu$ tall - E. arboreum

5. Spores 6-10 $\mu \mathrm{m}$, walls having a thinner region; peridium fugacious; columella cylindrical, tapering to fusiform, pale tan to dark brown - E. paucifilum

5. Spores 11-15 $\mu \mathrm{m}$, walls having thicker circular regions; peridium fugacious; columella cylindrical to irregular, hyaline; sporangia 300-500 $\mu \mathrm{m}$ tall - E. minutum

6. Spore walls having a uniform thickness -7 .

6. Spore walls having a thinner region -8 .

6. Spore walls having thicker circular regions -9 .

7. More than two spores produced; columella with a spore-like body generally present $-E$. apitectum

7. Only two spores produced; columella absent - E. bisporum

8. Columella a stalked hemispheric to lenticular spore-like-body - E. brooksii

8. Columella fusiform to cylindrical - E. fragile

9. Stalked hemispherical or lenticular columella present - E. corynophorum 
9. Crescent shape columella present - E. lunatum

9. Columella absent or a small cone, a spore-like-body may be present - 10 .

10. Stalk hollow or not filled with granular material - 11 .

10 Stalk filled with granular material - 12.

11. Spores 6.5-8 microns in diameter, golden brown, and often sticking together - E. elachiston

11. Spores 9-12 microns in diameter, white to yellowish white, separating - E. coelocephalum

12. Spores 6.5-8.7 $\mu \mathrm{m}$, thickened wall region consisting of two confronting crescents - E. ladoi

12. Spores 9-13 $\mu \mathrm{m}$, thickened wall region not consisting of two confronting crescents - E. colliculosum

13. Capillitium sparsely branching with no anastomosing - Barbeyella minutissima

13. Capillitium sparsely to moderately branching with some anastomosing - (Clastoderma) - 14 .

14. Capillitium forming a net without free ends - $C$. microcarpum

14. Capillitium with free end - 15.

15. Stipe with a mid-point swelling - $C$. debaryanum

15. Stipe lacking a mid-point swelling - C. pachypus

Echinosteliales G.W. Martin 1960. Mycologia 52: 127.

Minute stipitate (usually), globose sporangia; peridium delicate and generally fugacious except at the base where it may remain as a collar or persistent in whole or part, either splitting above into petaloid lobes which remain attached at the base; conical, cylindrical or fusiform columella usually present; capillitium of thin threads forming a complete open net to a few branched meshes or lacking; spores white to dark brown; stalk (generally) filled with granular material in lower region and closed in upper portions; Semimorula is sessile and lacks a columella and capillitium; protoplasmodium present.

Echinosteliaceae Rostafinski 1873 Vers. Syst. Mycetozoan 7.

Minute stipitate (usually), globose sporangia; peridium delicate and generally fugacious except at the base where it may remain as a collar; conical, cylindrical or fusiform columella usually present; capillitium of thin threads forming a complete open net to a few branched meshes or lacking; spores white to light brown; Semimorula is sessile and lacks a columella and capillitium; protoplasmodium present.

Echinostelium de Bary 1873. In Rostafinski, Vers. Syst. Mycetozoan 7.

$=$ ? Heimerleia Höhn. 1903. Ann. Mycol. 1: 391 .

Minute stipitate globose sporangia; peridium delicate and generally fugacious except at the base where it may remain as a collar; conical, cylindrical or fusiform columella usually present; capillitium of thin threads forming a complete open net to a few branched meshes or lacking; spores white to light brown; protoplasmodium present.

Echinostelium apitectum K.D. Whitney 1980. Mycologia 72: 954.

$=$ E. vanderpoelii Nann.-Bremek., D.W. Mitch., T.H Lakh. \& R.K Chopra 1991. Proc. Kon. Akad. Wetensch. 97: 411.

Types - BPI (Whitney 662), IMI, K, NY, UC

Sporotheca - scattered to gregarious; globose $(30-65 \mu \mathrm{m})$; hyaline to pinkish white and yellowish white when mature. Peridium: fugacious except for a small persistent collar. Capillitium: absent. Spores: globose $(6-11 \mu \mathrm{m})$, smooth to minutely roughened with walls of uniform thickness; pink to hyaline or yellowish white (in mass) or hyaline to pinkish grey to olive grey (in transmitted light). Columella: absent or if present then flattened, cylindrical or fusiform; light brown to black; often covered with a spore-like body. Stalk: 70-170 $\mu \mathrm{m}$ tall, thin and tapering, expanding below and filled with granular material; translucent and yellowish brown to nearly colorless. Hypothallus: discoid and inconspicuous, yellowish brown. Plasmodium: unknown. Habitat: on the bark of living trees. 
Distribution - Australia, Estonia, Lithuania, Mexico, Peru, Puerto Rico, Russia, South Africa, Spain, Turkey, Ukraine, US.

Similar species - E. colliculosum has spore walls with thickened circular regions; E. fragile has spore walls with a thinner region.

Echinostelium arboreum H.W. Keller \& T.E. Brooke 1976. Mycologia 68: 1207.

Types - BPI (Keller 1396), K, NY

Sporotheca - scattered to gregarious; globose $(40-50 \mu \mathrm{m})$; light yellow to moderate yellow when mature. Peridium: persistent shiny membranous clinging to capillitial tips; finally fugacious except for a large persistent collar. Capillitium: scanty to well developed, sparsely branching and not anastomosing; light yellowish threads with free ends Spores: globose $(5-7 \mu \mathrm{m})$; minutely roughened with walls of uniform thickness; yellow to yellowish white (in mass) or hyaline to pale yellow (in transmitted light). Columella: cylindrical $(20-30 \mu \mathrm{m}$ tall); white to yellowish white. Stalk: $60-110 \mu \mathrm{m}$ tall; thin, tapering with granular material in the lower region; translucent and light yellow. Hypothallus: discoid and inconspicuous, yellowish brown. Plasmodium: hyaline protoplasmodium. Habitat: on the bark of living trees.

Distribution - Lithuania, Mexico, Montenegro, Peru, Russia, South Africa, Spain, Turkey, Ukraine, US.

Similar species - E. elachiston has a rudimentary un-branching capillitium; E. minutum has a fugacious peridium and the spores have thickened circular regions.

Remarks - DNA and peridium indicates a relationship to Barbeyella.

Echinostelium bisporum (L.S. Olive \& Stoian.) K.D. Whitney \& L.S. Olive 1982. In Whitney, Bennett \& Olive, Mycologia 74: 680.

$\equiv$ Cavostelium bisporum L.S. Olive \& Stoian. 1966. Mycologia 58: 440.

Types - NY (Olive G-17)

Sporotheca - solitary to scattered; $10-20 \mu \mathrm{m}$ in diameter, two spores with one on top of the other. Peridium: fugacious except for a subsporangial collar. Capillitium: absent. Spores: globose $(7-10 \mu \mathrm{m})$; minutely punctuate with walls of uniform thickness; hyaline. Columella: absent. Stalk: 7-14 $\mu \mathrm{m}$ tall; thin, cylindrical with granular material in the base; hyaline. Hypothallus: discoid and inconspicuous, hyaline. Plasmodium: hyaline uninucleate amoeboid cell. Habitat: on bark, liter, and ground.

Distribution - Australia, Kenya, Russia, Sweden, US.

Similar species - E. lunatum has a number of spores and a crescent shaped columella; Cavostelium apophysatum has a hollow apophysis at the tip of the stalk and produces a single spore.

Remarks - an extremely minute species seldom seen except by specialists.

Echinostelium brooksii K.D. Whitney 1980. Mycologia 72: 057.

Types - BPI (Whitney 654), IMI, K, NY, UC

Sporotheca - scattered to gregarious; globose $(35-60 \mu \mathrm{m})$; grayish yellowish pink. Peridium: fugacious except for a persistent collar. Capillitium: absent. Spores: globose $(10-14 \mu \mathrm{m})$; minutely roughened walls with a diffuse thinner region; grayish yellowish pink (in mass) or hyaline to grayish yellowish pink (in transmitted light). Columella: stalked hemispherical to lenticular (3-5 $\mu \mathrm{m}$ tall) spore-like body; translucent and light brown to dark olive brown. Stalk: $65-140 \mu \mathrm{m}$ tall; thin and tapering at the apex, lower region filled with granular material; light pale yellow. Hypothallus: discoid and inconspicuous, light brown. Plasmodium: unknown. Habitat: on the bark of living trees and dead wood.

Distribution - Australia, Iceland, Lithuania, Russia, US.

Similar species $-E$. fragile has a fusiform columella; $F$. corynophorum has a pale to hyaline columella and the spore walls have thickened circular areas. 
Echinostelium coelocephalum T.E Brooks \& H.W Keller 1976. In Keller \& Brooks, Mycologia 66: 1212.

Types - BPI (Brooks 2688), Keller \& Brooks 1214

Sporotheca - scattered to gregarious; globose $(30-40 \mu \mathrm{m})$, white to yellowish white when mature. Peridium: persistent basally, reduce to a collar at maturity. Capillitium: absent. Spores: globose to subglobose $(9-12 \mu \mathrm{m})$; minutely roughened walls with prominent thickened circular regions; white to yellowish white (in mass) or hyaline (in transmitted light). Columella: absent, a spore-like body may occur on the tip of stalk. Stalk: 37-70 $\mu \mathrm{m}$ tall; thin, hollow and tapering at apex; translucent and light pale yellow. Hypothallus: discoid and inconspicuous, yellowish brown. Plasmodium: hyaline protoplasmodium. Habitat: on bark of living trees.

Distribution - Spain, Turkey, Ukraine, US.

Similar species $-E$. colliculosum is larger, the stalk is not hollow and the thickened circular spore wall regions are less distinct.

Remarks - seventeen isolates of a single biological species was found in California and Arizona with multiple mating type alleles (Haskins et al. 2000).

Echinostelium colliculosum K.D. Whitney \& K.W. Keller 1980. Mycologia 72: 641.

Types - BPI (Whitney 1132), K, NY, UC

Sporotheca - scattered to gregarious; globose $(30-50 \mu \mathrm{m})$; white to yellowish white when mature. Peridium: persistent basally, reduce to a collar at maturity; adheres to the spore like body. Capillitium: absent. Spores: globose $(9-13 \mu \mathrm{m})$; minutely roughened walls with thickened circular regions; white (in mass) or hyaline (in transmitted light). Columella: absent, spore-like body present on the stalk tip. Stalk: 70-120 $\mu \mathrm{m}$ tall; thin, tapering at apex, lower region filled with granular material; translucent and pale yellow. Hypothallus: discoid and inconspicuous, yellowish brown. Plasmodium: hyaline protoplasmodium. Habitat: on bark of living trees and Yucca. Turkey, US.

Distribution - Australia, India, Lithuania, Mexico, Peru Russia, South Africa, Spain,

Similar species - E. apitectum has spore walls of uniform thickness; E. coelocephalum is smaller, the stalk is hollow and the thickened circular spore wall regions are more distinct.

Echinostelium corynophorum K.D Whitney 1980. Mycologia 72: 963.

Types - BPI (Whitney 647), IMI, K, NY, UC

Sporotheca - scattered to gregarious; globose $(40-60 \mu \mathrm{m})$; white. Peridium: persistent basally, reduce to a collar at maturity. Capillitium: absent. Spores: globose $(8-15 \mu \mathrm{m})$; smooth to minutely roughened walls with thickened circular regions; white (in mass) or hyaline (in transmitted light). Columella: stalked hemispherical to lenticular (3.5-6 $\mu \mathrm{m}$ tall); light brown. Stalk: 50-130 $\mu \mathrm{m}$ tall; thin, tapering at the apex; lower region filled with granular material; translucent and hyaline. Hypothallus: discoid and inconspicuous, light tan. Plasmodium: hyaline protoplasmodium. Habitat: on bark of living trees.

Distribution - Australia, Iceland, US.

Similar species - E. brooksii has a dark columella and the spore walls have a diffused thinner region.

Echinostelium cribrarioides Alexop. 1961. Amer. Midl. Naturalist 66: 391.

Types - BPI on permanent loan from IA (GR-14-1960), Alexopoulos 391

Sporotheca - scattered to gregarious; globose $(60-120 \mu \mathrm{m})$; pale ochraceous. Peridium: fugacious except for a persistent collar. Capillitium: thin colorless threads forming a complete globose net with large meshes, occasionally with free ends. Spores: globose $(9-10 \mu \mathrm{m})$ smooth walled with thickened circular regions, cream colored (in mass) or colorless (in transmitted light). Columella: small (4-20 $\mu \mathrm{m}$ tall) column delimited from the stalk by the peridial collar. Stalk: 150 $350 \mu \mathrm{m}$ tall; thin and tapering, expanding below and filled with granular material; dark brown to 
nearly colorless. Hypothallus: discoid and inconspicuous, dark brown to nearly colorless. Plasmodium: hyaline protoplasmodium. Habitat: on the bark of living trees.

Distribution - Finland, Greece, Netherlands, South Africa, Turkey.

Similar species $-E$. minutum does not form a complete capillitial net.

Remarks - the capillitium resembles the peridial net of a Cribraria species.

Echinostelium elachiston Alexop. 1958. Mycologia 50: 52.

Types - BPI on permanent loan from IA (GR-194), Alexopoulos 52

Sporotheca - scattered or gregarious; erect or nodding; globose $(30-40 \mu \mathrm{m})$ golden brown fading to cream colored. Peridium: shiny transparent membranous becomes fugacious except for a large persistent collar. Capillitium: absent or rudimentary and not branching. Spores: globose (6.5-8 $\mu \mathrm{m})$ smooth walled with thickened circular regions, golden yellow to white (in mass) or light yellow to colorless (in transmitted light); often clinging together and dispersed as a mass. Columella: absent, or a minute cone. Stalk: 50-90 $\mu \mathrm{m}$ tall; thin and tapering; golden brown. Hypothallus: discoid and inconspicuous, dark brown to golden brown. Plasmodium: hyaline protoplasmodium. Habitat: on the bark of living trees.

Distribution - Australia, Greece, Ireland, Jamaica, Mexico, Puerto Rico, Russia, Ukraine, Turkey, US.

Similar species $-E$. arboreum has a branching capillitium; $F$. colliculosum has a spore-like body in place of a columella.

Echinostelium fragile Nann.-Bremek. 1961. Acta Bot. Neerl. 10: 65.

Types - Nannenga-Bremekamp 3868

Sporotheca - scattered or gregarious, erect or nodding, globose $(30-50 \mu \mathrm{m})$; very pale pink to salmon colored and becoming brownish. Peridium: fugacious except for a persistent minute collar. Capillitium: absent. Spores: subglobose $(12-15 \mu \mathrm{m})$ smooth walled with a small thinner area; pale pink or gray (in mass and in transmitted light). Columella: fusiform (6 $\mu \mathrm{m}$ tall) and brown. Stalk: $70-130 \mu \mathrm{m}$ tall; tapering, sometimes slightly striate, filled with granular matter at the base; hyaline. Hypothallus: discoid and inconspicuous, light brown to colorless. Plasmodium: hyaline to pale pink protoplasmodium. Habitat: on the bark of living trees.

Distribution - Chile, England, Iceland, Ireland, Montenegro, Netherland, Switzerland, US. capillitium.

Similar species $-E$. brooksii does not have a fusiform columella; $F$. paucifilum has a sparse

Echinostelium ladoi Pando 1997. Mycotaxon 64: 343.

Types - MA-fungi 22593 (Pando 613), Pando 343

Sporotheca - isolated to scattered; globose $(35-40 \mu \mathrm{m})$; white. Peridium: inconspicuously persistent at base as a collar. Capillitium: absent. Spores: globose $(6.5-8.5 \mu \mathrm{m})$; minutely roughened walls with prominent thickened circular regions consisting of two confronted crescents; white (in mass) or hyaline (in transmitted light). Columella: absent; a spore like body may be present. Stalk: 12-200 $\mu \mathrm{m}$ tall; thin, tapering with lower region filled with granular material; translucent and hyaline to moderately yellow. Hypothallus: discoid and inconspicuous, light tan. Plasmodium: unknown. Habitat: on the bark of living trees.

Distribution - Spain.

Similar species - E. apitectum, E. brooksii, and E. paucifilum spores have thickened circular regions that do not consist of two confronting crescents.

Echinostelium lunatum L.S Olive \& Stoian. 1971. Mycologia 63: 1051.

Types - NY (Olive PR-24)

Sporotheca - scattered to gregarious; globose $(25-50 \mu \mathrm{m})$; pink to light orange. Peridium: fugacious except for a minute collar. Capillitium: absent. Spores: globose $(6-13 \mu \mathrm{m})$; minutely roughened with thickened circular regions; hyaline to light pink (in mass) or hyaline (in transmitted 
light). Columella: crescent shaped and half circular; light brown. Stalk: $15-30 \mu \mathrm{m}$ tall; thin, tapering at the apex, filled with granular material; translucent and hyaline. Hypothallus: discoid and inconspicuous, light tan. Plasmodium: minute hyaline to pink protoplasmodium. Habitat: on the bark of living trees and vines, and on dead attached plant parts.

Distribution - Puerto Rico, US.

Similar species $-E$. bisporum has only two spores and has no columella.

Remarks - the minute size makes for difficult detection and examination.

Echinostelium minutum de Bary 1873. In Rostafinski, Sluzowce Monogr. 213.

= Heimerleia hyalina Höhn. 1903. Ann. Mycol. 1: 391 .

Types - BPI (Whitney 465) neotype

Sporotheca - scattered to gregarious, globose $(40-70 \mu \mathrm{m})$ pale pinkish to white. Peridium: fugacious except for a persistent collar. Capillitium: scanty and colorless, several times forked with hooked free ends. Spores: globose $(7-8 \mu \mathrm{m})$ smooth walled with thickened circular regions; pinkish to white (in mass) or pallid to colorless (in transmitted light). Columella: very short column blending into the capillitium. Stalk: $210-490 \mu \mathrm{m}$ tall; thin and tapering, expanding below and filled with granular material; hyaline to whitish yellow. Hypothallus: discoid and inconspicuous, light brown to colorless. Plasmodium: hyaline to pink protoplasmodium. Habitat: on bark of trees and vines, attached dead plant parts, dead wood, dung and litter.

Distribution - cosmopolitan.

Similar species - E. cribrarioides has a complete capillitial net

Remarks - a worldwide species complex consisting of many apomictic isolates and a number of biological species (Clark \& Haskins 1998, 2010).

Echinostelium paucifilum K.D. Whitney 1980. Mycologia 72: 974.

Types - BPI (Whitney 657), IMI, K, NY, UC

Sporotheca - scattered to gregarious; globose $(45-70 \mu \mathrm{m})$; grayish yellowish pink. Peridium: persistent basally, reduced to a collar at maturity. Capillitium: sparsely branching and anastomosing thin threads with free end; light brown to hyaline. Spores: globose (11-15 $\mu \mathrm{m})$; minutely roughened walls with a thinner region; hyaline to grayish yellowish pink (in mass) or hyaline (in transmitted light). Columella: short cylinder $(22-30 \mu \mathrm{m}$ tall); light brown to dark olive brown. Stalk: 140-225 $\mu \mathrm{m}$ tall; thin, tapering at the apex, filled with granular material; translucent and light brown to hyaline. Hypothallus: discoid and inconspicuous, light brown.

Plasmodium: unknown. Habitat: on the bark of living trees.

Distribution - Japan, US.

Similar species $-E$. ladoi has spores with thickened confronting crescents; $E$. fragile has no capillitium; E. minutum has smaller spores with walls with circular thickened regions.

\section{Invalid species of Echinostelium}

Echinostelium roseum Ing 1965. Trans. Brit. Mycol. Soc. 48: 650.

Types - IMI 112129

Remarks - Nom. conf. (a Myxobacter) See Ing 1984. Trans. Brit. Mycol. Soc. 82: 173

Semimorula E.F. Haskins, McGuin. \& C.S. Berry 1983. Mycologia 75: 153.

Minute hemispherical sessile sporangium with a thin transparent peridium and lacking capillitia and a columella; colorless spores which release the amoeboflagellate by dissolution of the spore wall; protoplasmodium present.

Semimorula liquescens E.F. Haskins, McGuin. \& C.S. Berry 1983. Mycologia 75: 153.

Types - BPI (Haskins 848), NY, UC, K, WTU.

Sporotheca - solitary to gregarious, hemispherical $(25-45 \mu \mathrm{m})$ colorless. Peridium: thin and transparent. Capillitium: absent. Spores: globose $(7.5-13 \mu \mathrm{m})$, smooth with no ornamentation by 
light or electron microscopy; colorless. Hypothallus, Stalk and Columella: absent. Plasmodium: small hyaline protoplasmodium. Habitat: on dried infructescences of Solidago, and Lythrum spp. and dried leaves of Phragmites spp.

Distribution - US (Washington and Massachusetts).

Similar species - none.

Remarks - DNA phylogenetic studies (Fiore-Donno et al. 2009, Kretschmar et al. 2015) indicate that this unique species is closely related to Echinostelium corynophorum.

Clastodermataceae Alexop. \& T.E. Brooks 1971. Mycologia 63: 926.

Peridium fugacious except for a basal collar or persistent in whole or part, splitting above into petaloid lobes which remain attached at the base; spores brown in mass; protoplasmodium present.

Clastoderma A. Blytt 1880. Bot. Zeitung 38: 343.

= Orthotricha Wingate 1886. J. Mycol. 2:123. (non Orthotrichum Hedw. 1789).

= Wingina Kuntze 1891. Revis. gen. pl. 1-2: 875 .

Minute stipitate globose sporangia; peridium fugacious except for a collar at the base; columella short or lacking; capillitium of branching and sparsely anastomosing threads arising from the columella or the base of the sporangium; spores brown; protoplasmodium present.

Clastoderma debaryanum A. Blytt 1880. Bot. Zeitung 38: 343.

$=$ Orthotricha microcephala Wingate 1886. J. Mycol. 2:125.

= Wingina microcephala (Wingate) Kuntze 1891. Revis. Gen. Pl. 1-2: 875.

=C. debaryanum var. imperataria Emoto 1929. Bot. Mag. (Tokyo) 43: 169.

$=$ C. dictyosporum TN. Lakh. \& KG. Mukerji 1976. Norweg. J. Bot. 23: 110.

Types - none.

Sporotheca - scattered or gregarious, globose $(100-200 \mu \mathrm{m})$, light brown. Peridium: dehiscent with minute fragments which may remain attached to the platelet tips of the capillitium and form a persistent basal collar attached to the stalk; rosaceous brown. Capillitium: sparsely branching and anastomosing pale brown threads with flared platelet tips. Spores: globose (8-10 $\mu \mathrm{m}$ ); covered with very blunt coarse warts; rosaceous-brown (in mass) or pallid (in transmitted light). Columella: very short to moderate $(30 \mu \mathrm{m})$ cylindrical column blending into the capillitium; brown. Stalk: 900-1100 $\mu \mathrm{m}$ tall, slender, stuffed with dark granular material below, translucent and brown above, the two portions divided by a prominent oval swelling. Hypothallus: discoid and inconspicuous, dark brown to black. Plasmodium: watery white protoplasmodium becoming greenish to blackish with age. Habitat: on dead wood and debris, bark of living and dead trees.

Distribution - cosmopolitan (abundant in the tropics).

Similar species - Comatricha elegans lacks the stalk swelling.

Remarks - somewhat variable in terms of its morphology (Eliasson \& Keller 1996) and DNA profiles (Kretschmar et al. 2015.

Clastoderma microcarpum (Meyl.) Kowalski 1975. Mycologia 67: 475.

$\equiv$ Comatricha elegans (Racib.) G. Lister var. microcarpa Meyl. 1935. Bull. Soc. Vaud. Sci, Nat. 58:423.

Types - LAU (Yamashiro \#53).

Sporotheca - scattered; globose (170-250 $\mu \mathrm{m})$; reddish brown. Peridium: fugacious except for a small persistent collar. Capillitium: sparsely branching and anastomosing reddish brown threads forming a wide-meshed surface net with no free ends and no or few peridial platelets (membranous expansions on the surface net). Spores: globose $(13.5-15 \mu \mathrm{m})$ smooth to slightly verruculose; reddish brown (in mass) or pale violet brown (in transmitted light). Columella: cylindrical (1/5 of sporotheca) column blending into the capillitium; reddish brown. Stalk: 200-400 $\mu \mathrm{m}$ tall; thin, tapering with granular material in the lower region, translucent and reddish brown to 
jet black below. Hypothallus: discoid and inconspicuous, black. Plasmodium: unknown Habitat: on bark of living trees.

Distribution - Japan, Austria, US.

Similar species - Clastoderma pachypus lacks a capillitial surface net with no free end; Comatricha elegans is larger and not forming a capillitial surface net lacking free end.

Remarks - further collections may find that this species grades into Clastoderma pachypus.

Clastoderma pachypus Nann.-Bremek. 1968. Proc. Kon. Ned. Akad. Wetensch. 71: 44.

Types - Nannenga-Bremekamp 6768, BM, IA, K, L, UT.

Sporotheca - scattered to gregarious; globose $(75-125 \mu \mathrm{m})$; rosaceous brown to moderate brown. Peridium: dehiscent except for a small persistent collar; light brilliant yellow to moderate yellow. Capillitium: sparsely branching and seldom anastomosing violet brown to brown threads with peripheral loops having small terminal platelets. Spores: globose $(10-13 \mu \mathrm{m})$; faintly spinulous; brown (in mass) or light brown gray (in transmitted light). Columella: absent to cylindrical (1/3 of sporotheca) column blending into the capillitium; dark olive brown to black. Stalk: $115-330 \mu \mathrm{m}$ tall; thin, tapering with granular material in the lower region; translucent and red brown to yellow brown below. Hypothallus: discoid and inconspicuous, yellowish brown. Plasmodium: hyaline protoplasmodium. Habitat: on the bark of living trees.

Distribution - Australia, Costa Rica, Dominica, France, Ireland, Mexico, Spain, United Kingdom, Japan, India, US.

Similar species -Clastoderma microcarpum has a capillitial surface net with no free ends. microcarpum.

Remarks - further collections may find that this species grades into Clastoderma

Barbeyella Meyl. 1914. Bull. Soc. Bot. Genève 6: 89.

Minute stipitate globose sporangia with a columella; peridium dehiscent by petaloid lobes; dark stalk filed with dark granules, columella an extension of the stalk and giving rise to a few simple or sparsely branched capillitial threads; spores dark; protoplasmodium present.

Barbeyella minutissima Meyl. 1914. Bull. Soc. Bot. Genève 6: 89.

Types - LAU (Meylan Oct. 1913).

Sporotheca - scattered or gregarious, globose $(100-200 \mu \mathrm{m})$, violaceous to brownish black. Peridium: dehiscing by 5-9 lobes and attached to the capillitial tips, violaceous and somewhat shining, impregnated with dark granules. Capillitium: seven to ten simple to sparsely branching brown threads arising from the columella and attached to the peridial platelets. Spores: globose (7$9 \mu \mathrm{m}$ ), heavily warted to occasionally somewhat smooth; brown (in mass) or light brown (in transmitted light). Columella: short brownish extension of the stalk. Stalk: 0.300-700 $\mu \mathrm{m}$ tall, slender, filled with dark granules, blackish brown. Hypothallus: discoid and inconspicuous, dark brown to black. Plasmodium: white protoplasmodium becoming dark brown with age. Habitat: apparently restricted generally to montane spruce fir forests; on decaying logs associated with mosses, liverworts and algae.

Distribution - Finland, Germany, Japan, Poland, Sweden, Switzerland, Mexico, US. Similar species - Licea opercula has a sporothecal lid and no columella or capillitium.

Remarks - Seems to be restricted to its unique habitat.

\section{Acknowledgement}

This guide is an attempt to distill the work and ideas of many researchers; however, such an attempt can never do justice to everyone's contributions, and we can only say that we tried to do our best, and hope that we have not committed too many major omissions. 


\section{References}

Aldrich HC, Blackwell M. 1976 - Resistant structures in the myxomycetes. In (eds. Weber D, Hess

W.) The fungal spore, form and function. John Wiley and Sons, New York.

Aldrich HC. 1968 - The development of flagella in swarm cells of the myxomycete Physarum flavicomum. Journal of General Microbiology 50, 217-22.

Alexopoulos CJ, Brooks TE. 1971 - Taxonomic studies in the myxomycetes III. Clastodermataceae: a new family of the Echinosteliales. Mycologia 63, 925-928.

Alexopoulos CJ. 1958 - Three new species of myxomycetes from Greece. Mycologia 48, 50-56.

Alexopoulos CJ. 1960 - Morphology and laboratory cultivation of Echinostelium minutum. American Journal of Botany 47, 37-43.

Alexopoulos CJ. 1961 - A new species of Echinostelium from Greece. American Midland. Naturalist 66, 391-394.

Alexopoulos CJ. 1969 - The experimental approach to the taxonomy of the myxomycetes. Mycologia 61, 103-116.

Blytt AG. 1880 - Clastoderma A. Blytt, novem Myxomycetum genus. Botanische Zeitung 38, 343.

Clark J, Haskins EF. 1998 - Heterothallic mating systems in the Echinostelium minutum complex. Mycologia 90, 382-388.

Clark J, Haskins EF. 2010 - Reproductive systems in the myxomycetes: a review. Mycosphere 1, 337-367.

Clark J, Haskins EF. 2013 - The nuclear reproductive cycle in the myxomycetes: a review. Mycosphere 4, 337-353.

Eliasson U, Keller H. 1996 - The genus Clastoderma: taxonomic evaluation and intraspecific variation of $C$. debaryanum. Mycological Research 100: 601-609.

Elliott EW. 1949 - The swarm-cells of myxomycetes. Mycologia 41, 141-170.

Emoto Y. 1929 - Über neue Myxomyceten. Botanical Magazine (Tokyo) 43, 169-173.

Eumycetozoan Project - http//slimemold.uark.edu/index.htm (2015).

Fiore-Donno AM, Haskins EF, Pawlowski J, Cavalier-Smith T. 2009 - Semimorula liquescens is a modified echinostelid myxomycete (Mycetozoa). Mycologia 101, 773-776.

Fiore-Donno AM, Kameno A, Meyer M, Schnittler M, Fukui M, Cavalier-Smith T. 2012 - 18S rRNA phylogeny of Lamproderma and allied genera (Stemonitales, Myxomycetes, Amoebozoa). PLoS One 7, e35559.

Frederick L, Roth IL, Pendergrass L. 1986. Observations on the "Peridial Platelet" of Clastoderma debaryanum. Mycologia 78, 263-268.

Furtado JS, Olive LS, Jones SB. 1971 - Ultrastructure studies of protostelids: the fruiting stage of Cavostelium bisporum. Mycologia 63, 132-143.

Goodwin DC. 1961 - Morphogenesis of the sporangium of Comatricha. American Journal of Botany 48, 148-154.

Gray WD. 1937 - Observations on the method of stipe formation in Stemonitis and Comatricha. Proceedings of the Indiana Academy of Science 45, 81-85.

Haskins EF, Hinchee AA, Cloney RA. 1971 - The occurrence of synaptonemal complexes in the slime mold Echinostelium minutum de Bary. Journal of Cell biology 51, 898-905.

Haskins EF, Hinchee AA, McGuinness M. 1985 - The amoebal and protoplasmodial cyst phase of Echinostelium minutum. Mycologia 77, 253-258.

Haskins EF, Hinchee AA. 1974 - Light and ultra-microscopic observations on the surface structure of protoplasmodium, aphanoplasmodium, and phaneroplasmodium

(Myxomycetes).

Canadian Journal of Botany 52, 1835-1839.

Haskins EF, Hinchee AA. 1992 - Spore germination in Echinostelium minutum. Mycologia 84, 916-920.

Haskins EF, Kerr NS. 1976 - Vergleich des Plasmodien-Typen und der Sporulatin bei Myxomyceten. Film C1220 der Institut fûr Wissenschaftlichen Film, Göttingen. Publikationen zu Wissenschaftlichen Film, Sektion Biologie 11, 1-34. 
Haskins EF, McGuinness M. 1989 - Sporophore ultrastructure of Echinostelium arboreum. Mycologia 81, 303-307.

Haskins EF, McGuinness MD, Berry CS. 1983 - Semimorula: new genus with myxomycete and protostelid affinities. Mycologia 75, 153-158.

Haskins EF, McGuinness MD, Clark J. 2000 - Heterothallic mating systems in the Echinosteliales II. Echinostelium coelocephalum. Mycologia 92, 1080-1084.

Haskins EF, McGuinness MD. 1986 - Comparative ultrastructure observations of spore wall structure of six species of Echinostelium and three species of Eumycetozoa. Mycologia 76, 613-618.

Haskins EF, Therrien CD. 1978 - The nuclear cycle of the myxomycete Echinostelium minutum I. Cytophotometric analysis of DNA of the amoebal and plasmodial phases. Experimental Mycology 2, 32-40.

Haskins EF, Wrigley de Basanta, D. 2008 - Methods of agar culture of myxomycetes: an overview. Revista Mexicana de Micologia 27, 1-7.

Haskins EF. 1970 - Axenic culture of myxamoebae of the myxomycete Echinostelium minutum. Canadian Journal of Botany 48, 663-664.

Haskins EF. 1971 - Sporophore formation in the myxomycete Echinostelium minutum de Bary. Archiv für Protistenkund 113, 123-130.

Haskins EF. 1973a - Echinostelium minutum (Myxomycetes) - plasmodia stage. Film E1816 der Institut fûr Wissenschaftlichen Film, Göttingen. Publikationen zu Wissenschaftlichen Film, Sektion Biologie 8, 55-66.

Haskins EF. 1973b - Echinostelium minutum (Myxomycetes) - amoebal stage. Film E1817 der Institut fûr Wissenschaftlichen Film, Göttingen. Publikationen zu Wissenschaftlichen Film, Sektion Biologie 9, 235-245.

Haskins EF. 1978a - A study of the amoebo-flagellate transformation in the slime mold Echinostelium minutum de Bary. Protoplasma 94, 193-206.

Haskins EF. 1978b - The occurrence of binary plasmotomy in the protoplasmodium of the white spored Echinostelium minutum. Mycologia 70, 192-196.

Haskins EF. 1988 - Miss Guliema Lister's observations on the myxomycete Echinostelium minutum. Mycologia 80, 855-855

Hung CY, Olive LS. 1972 - Ultrastructure of the spore wall in Echinostelium. Mycologia 64, $1160-1163$.

Ing B. 1965 - Notes on myxomycetes. Transactions of the British Mycological Society 48, 647652.

Ing, B. 1984 - The identity of Echinostelium roseum (Myxomycetes).Transactions of the British Society 82, 173.

Jahn E. 1931 - Myxomycetenstudien. 13. Die Stielbildung bei den Sporangien der Gattung Comatricha. Berichte der Deutschen Botanischen Gesellschaft 49, 77-82.

Jump JA. 1954 - Studies on sclerotization in Physarum polycephalum. American Journal of Botany 26, 561-567.

Keller HW, Brooks TE. 1976 - Corticolous myxomycetes V. Observations on the genus Echinostelium. Mycologia 68, 1204-1220.

Koevenig JL. 1964 - Studies on life cycle of Physarum gyrosum and other myxomycetes. Mycologia 56, 170-164.

Kowalski DT. 1975 - The myxomycete taxa described by Charles Meylan. Mycologia 67, 448494.

Kretschmar M, Kuhn A, Bonkkawski M, Fiore-Donno A-M. 2015 - Phylogeny of the highly divergent Echinosteliales (Amoebozoa). Journal of Eukaryotic Microbiology doi:10.1111/jeu.12289

Kuntze CEO. 1891 - Revisio generum plantanum 1-2, 1-1011.

Lakhanpal TN, Mukerji KG. 1976 - Taxonomic studies on Indian myxomycetes I. The order Echinosteliales in India. Norwegian Journal of Botany 23, 107-111. 
Martin GW. 1960 - The systematic position of the Myxomycetes. Mycologia 52, 119-129.

McManus MA. 1961 - Laboratory culture of Clastoderma debaryanum. American Journal of Botany 48, 884-888.

Meylan C. 1914 - Myxomycètes du Jura (Suite). Bulletin de la Société Botanique Genève 6, 8690.

Meylan C. 1935 - Myxomycètes japonaise. Bulletin de la Société Vaudoise des Sciences Naturelles 58, 321-324.

Mims CW. 1972 - Spore-wall formation in the myxomycete Arcyria cinerea. Transactions of the British Mycological Society 59, 477-481.

Nannenga-Bremekamp NE. 1961 - Myxomycetes collected in the Netherlands, chiefly in the vicinity of Doorwerth (Geldland). Acta Botanica Neerlandia 10, 56-66.

Nannenga-Bremekamp NE, Mitchell DW, Lakhanpal TN, Chropra RK. 1991 - Echinostelium vanderpoelii a new widespread myxomycete. Proceedings Konenklijke Nederlandse Akademie van Wetenschappen, Series C 94: 411-413.

Nannenga-Bremekamp NE.1968 - Notes on myxomycetes XV. New species of Oligonema, Licea, Clastoderma, Comatricha, Paradiacheopsis and Badhamia. Proceedings Konenklijke Nederlandse Akademie van Wetenschappen, Series C 71, 41-51.

Olive LS, Stoianovitch C. 1966 - A new two-spored species of Cavostelium (Prostelida). Mycologia 58, 440-451

Olive LS, Stoianovitch C. 1971 - A minute new Echinostelium with protostelid affinities. Mycologia 63, 1051-1062.

Olive LS. 1960 - Echinostelium minutum. Mycologia 52, 159-161.

Pando F. 1997 - A new species and a synonymy of Echinostelium (Myxomycetes). Mycotaxon 64, 343-348.

Pando F. 1999 - The Echinosteliales (Myxomycetes): an INTKEY package for interactive, illustrated identification and information retrieval.http://www.rjb,csis.es/bioinformatics/echinos/E_intro.html (2015).

Ross IK, Shipley GL. 1973 - Sexual and somatic fusion in the heterothallic slime mold Didymium iridis 2. Effects of actinomycin D, cyclohexamide and lysosome stabilizers. Microbios 7, 165-171.

Ross IK. 1957 - Syngamy and plasmodial formation in the Myxomycetes. Journal of Botany 44, 843-850.

Ross IK. 1973 - The Stemonitomycetidae, a new subclass of Myxomycetes. Mycologia 65, 477485.

Rostafinski J. 1873 - Versuch eines Systems des Mycetozoen. Inaugural-dissertation, Strassburg.

Scheetz RW, Alexopoulos CJ. 1971 - The spores of Bahamia gracilis (Myxomycetes). Transactions of the American Microscopical Society 90, 473-475.

Scheetz RW, Alexopoulos CJ. 1976 - Studies of the spores of myxomycetes II. Physarum staminipes. Mycotaxon 4, 335-339.

Schnittler M, Stephenson SL, Novozholov YK. 2000 - Ultrastructure of Barbeyella minutissima (Myxomycetes). Karstenia 40, 159-166.

Shipley GL, Holt CE. 1982 - Cell fusion competence and its induction in Physarum polycephalum and Didymium iridis. Developmental Biology 90, 110-117.

Therrien CD, Haskins EF. 1981 - The nuclear cycle of the myxomycete Echinostelium minutum II. Cytophotometric analysis of the nuclear DNA content of the sporangial phase. Experimental Mycology 2, 269-235.

von Höhnel F. 1903 - Mycologische fragmente. Annales Mycologici Editi in Notitiam Scientiae Mycologicae Universalis 1, 391-392.

Weldon A. 1955 - Capillitial development in the myxomycetes Badhamia gracilis and Didymium iridis. Mycologia 47, 714-728.

Whitney KD, Bennett WE, Olive LS. 1982 - Observations on Echinostelium bisporum. Mycologia $74,677-680$. 
Whitney KD, Keller HW. 1980 - A new species of Echinostelium. Mycologia 72, 640-643.

Whitney KD. 1980 - The myxomycete genus Echinostelium. Mycologia 72, 950-987.

Whitney KD. 1982 - A survey of the corticolous myxomycetes of California. Madroňo 29, 259263.

Wingate H. 1886 - A new genus of Myxomycetes. Journal of Mycology 2, 125-126 